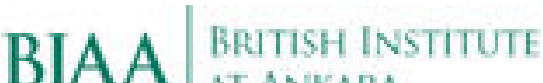

A History of Deforestation as Indicated by Charcoal Analysis of Four Sites in Eastern Anatolia Author(s): G. H. Willcox

Source: Anatolian Studies, Vol. 24 (1974), pp. 117-133

Published by: British Institute at Ankara

Stable URL: http://www.jstor.org/stable/3642603

Accessed: 07/01/2010 09:38

Your use of the JSTOR archive indicates your acceptance of JSTOR's Terms and Conditions of Use, available at http://www.jstor.org/page/info/about/policies/terms.jsp. JSTOR's Terms and Conditions of Use provides, in part, that unless you have obtained prior permission, you may not download an entire issue of a journal or multiple copies of articles, and you may use content in the JSTOR archive only for your personal, non-commercial use.

Please contact the publisher regarding any further use of this work. Publisher contact information may be obtained at http://www.jstor.org/action/showPublisher?publisherCode=biaa.

Each copy of any part of a JSTOR transmission must contain the same copyright notice that appears on the screen or printed page of such transmission.

JSTOR is a not-for-profit service that helps scholars, researchers, and students discover, use, and build upon a wide range of content in a trusted digital archive. We use information technology and tools to increase productivity and facilitate new forms of scholarship. For more information about JSTOR, please contact support@jstor.org.

British Institute at Ankara is collaborating with JSTOR to digitize, preserve and extend access to Anatolian Studies. 


\title{
A HISTORY OF DEFORESTATION AS INDICATED BY CHARCOAL ANALYSIS OF FOUR SITES IN EASTERN ANATOLIA
}

\author{
By G. H. WILLCOX
}

During the 1972 season of the Aşvan excavations (see French, 1973, p. 77) it was decided that, given the huge quantity of charcoal recovered (292 samples) from the four sites by water-sieving and trench sampling from strata which cover a period of c. 4,500-5,000 years, an analysis of the charcoals would prove revealing. Part of the aim of the research is to evaluate what information is available from charcoals recovered by modern methods, and to determine if it is possible to draw sound conclusions about vegetational changes which have not been fully recorded for the late Holocene in Eastern Anatolia. Although some data has been made available through pollen analysis (see van Zeist, 1968, pp. 19-39) the distribution, duration and composition of the forest which existed before deforestation is not entirely understood.

A dearth of necessary data on which to base this work made contemporary studies a prerequisite. Firstly an adequate comparative collection of identified modern woods had to be built up to aid identification of ancient charcoals. Secondly, a reliable method of sub-sampling had to be devised in order to deal with the copious material. And thirdly, a study of the modern habitats, ecological status and uses of arboreal species in the area today had to be made to act as a baseline from which one can extrapolate into the past using the data from charcoal analysis.

\section{GEOGRAPHICAL SETTING}

Aşvan is situated on the south bank of the River Murat at an elevation of $720 \mathrm{~m}$. just east and upstream of where it forms a confluence with the Euphrates, in the barren, rugged landscape of the Upper Euphrates Basin. To the north the horizon is dominated by the Munzur mountains, while to the south and west the terrain is typical of the austere Central Anatolian Plateau through which the Murat drains west from its source near lake Van, cutting a deep valley through the hills between Muş and Bingöl but opening onto the broad fertile plain, the Altınova, which will form the upstream boundary of the huge lake to be formed by the dam at Keban $80 \mathrm{~km}$. to the west. Below Keban the river turns sharply south, winding its way to Syria.

The region is well characterized climatically. From an ecological point of view the main features of the climate are continentality with extreme ranges in temperature both diurnally and annually, low precipitation, and two dormant seasons of plant growth, one during the hot dry summer, the other during the severe cold winter (Zohary, 1973, pp. 33 and 87). These features result in slow growth of plants, and hence slow forest regeneration. Throughout January the soil is frozen to a depth of $5 \mathrm{~cm}$. with a mean temperature of near $0^{\circ} \mathrm{C}$ necessitating the use of fuel for heating, while in July the mean is $27 \cdot 2^{\circ} \mathrm{C}$ (Wagstaff, 1973 , p. 199). Mean annual precipitation for the period 1929-71 at Elâzı ğ was $433.2 \mathrm{~mm}$., the rainy season being from October to May but with peaks in November and April. Mean annual potential evaporation greatly exceeds mean 
annual precipitation. It is assumed for purposes of interpretation of palaeobotanical data that the climate has not, over the last 5,000 years, changed sufficiently to have brought about radical changes in the flora.

The study area defined by the boundary of the Aşvan bölgesi contains eleven archaeological sites and eleven modern settlements. Geologically the area is varied, with Cretaceous limestone, gabbro and diorite overlaid by Eocene flysch of marl, sandstone and conglomerate, with Miocene facies above these, while the valley bottom has a large area of recent alluvium (Wagstaff, 1973, p. 205). Wagstaff described five distinct topographical units in the area (see Fig. 1): the valley bottom, the upper flood plain, the village plain, fringing hills, and the undulating upland basin which is flanked by hills to the east and west. Within the region a number of perennial springs issue from beneath the conglomerate, forming cool streams which are extensively tapped for irrigation (see Fig. 1) but also they provide a habitat for hydrophilic trees and shrubs. Pedologically, variation must exist, though no survey has been carried out. Certainly the flood plain attracts halophytes. Many upland areas have a dearth of soil which could be attributed to erosion, accelerated by deforestation, while the village plain has a thick stoneless deposit whose origin may be the fringing hills (Wagstaff, 1973, p. 210). The artificial area of study is useful from the point of view of settlement analysis and land usage but limited in terms of an area from which timber may have been collected. For example, logs may have been floated down the river, or felled on the other side and floated across. Sampling obviously had to be made over a very much larger area. This then is the physical environment where for the past 7,000-8,000 years (French, 1973, p. 191) peoples have strived to subsist during periods of occupation as an integral part of the ecosystem which underwent changes, and so, by a process of feed-back would produce cultural adaptations. Our aim is to trace the changes in forest cover resulting directly or indirectly from cultural activities. Indicators of these changes are, it is hoped, preserved at least in part through the use of timber and tinder which has become incorporated as charcoal in the stratified deposits. As a starting point, an understanding of the arboreal flora of the region and its phytogeographical status is a prerequisite for interpretation of palaeobotanical data.

\section{THE CONTEMPORARY BOTANICAL STATUS OF THE REGION}

Today the vegetation of the Aşvan bölgesi appears to consist largely of a plagioclimax maintained by heavy grazing by mixed herds, arable farming, and the occasional fire. An ecological evaluation of territory cannot be made unless a clear knowledge of the climatic climax is obtained. This is made difficult by historical circumstances which would appear to have led to almost complete obliteration of the climax association so that the limiting factor of competition has been removed, thus allowing formerly minor species to expand and aliens to invade and colonize the area. A picture of the theoretical climatic climax can be built up by examination of small inaccessible relict regions which appear to be isolated from the anthropogenic factors. On the other hand some authorities believe that evaluation should rely on the present distribution, making no a priori assumptions about the past climatic climax. This method may, however, underrate the "natural" influence of man which, like other ecological factors, are undoubtedly 


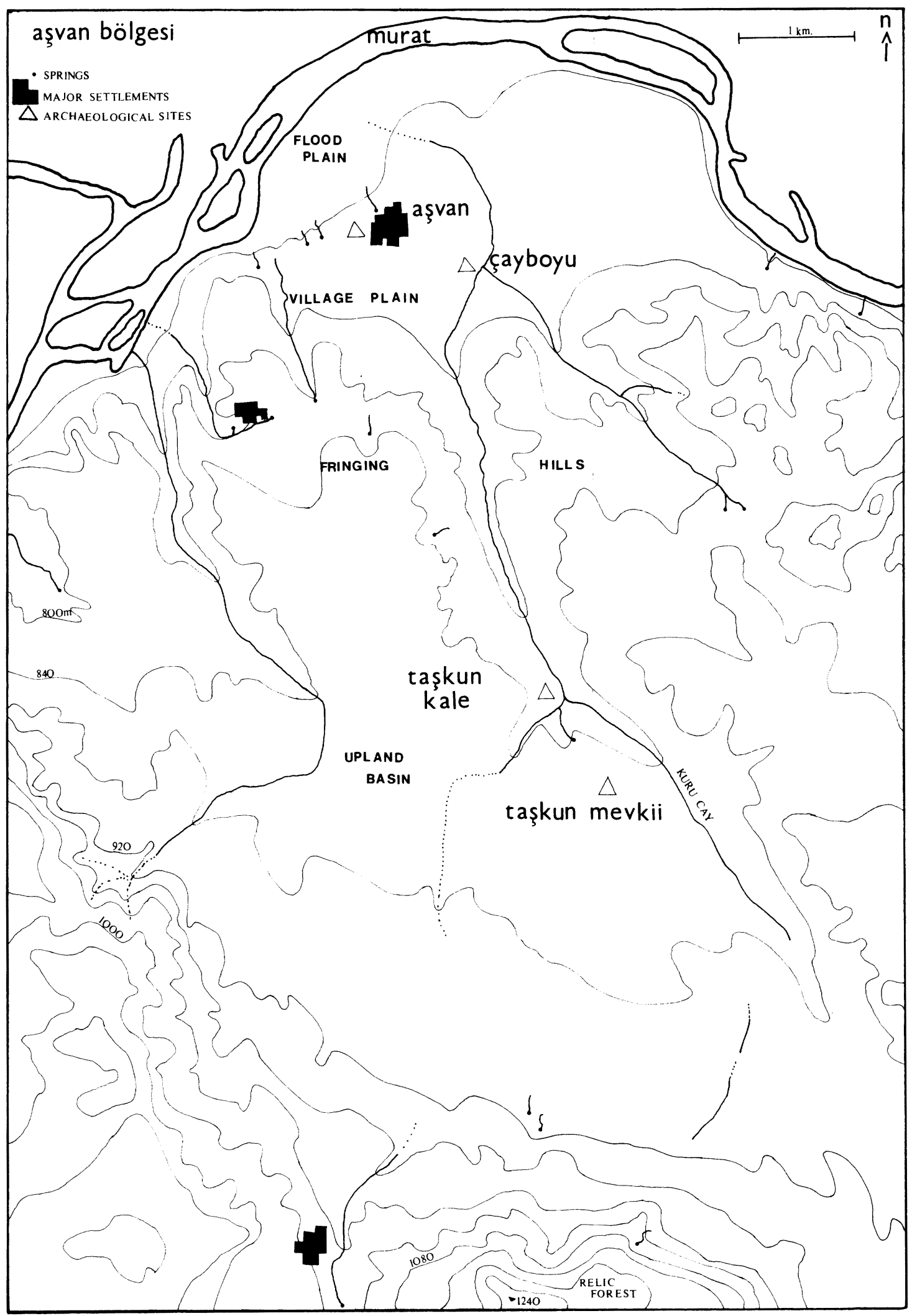

FIG. 1. Map showing positions of the major past and present settlements in relation to topography and water resources. 
manifest in the biotic environment (for a discussion of these methodologies see Davis, 1971, p. 51). According to Zohary, Aşvan lies in the Irano-Turanian phytogeographical region which theoretically would form the Kurdo-Zagrosian xerophilous deciduous steppe-forest climax association (Zohary, 1973, Map 7). These now impoverished forests are characterized by a discontinuous canopy of predominantly Quercus with a rich ground flora. However, further complications arise due to the close proximity of the Mediterranean region to the south, the sub-Euxine mesic forests to the north and disagreement between authorities over the territory to the west. Nevertheless on excursions collecting reference material into the foothills of the Munzur mountains $40 \mathrm{~km}$. to the north. where more arboreal vegetation has survived, it became clear that many species are endemic to the Irano-Turanian region, Aşvan being in the extreme north-west of the region which runs south-east along the belt of high rainfall which follows the Zagros mountains to the Persian Gulf (Zohary, 1973, pp. 181. 188, 199 and 277).

It is now necessary to study the flora of the Aşvan bölgesi in more detail for man sought the optimum and hence atypical situation to meet his needs: this is true of Aşvan where there is an abundance of hydrophilic species.

The flora of the Aşvan bölgesi can be divided into three ecological groups. Emphasis here is on the trees and shrubs, together with their utilization in the villages today.

1. Arable and Village Habitat. In the village itself are found a number of introduced species. These include mulberry (Morus alba), which is cultivated near permanent water for its edible fruits, fine timber and in the past for silk production. The timber is occasionally used for beams and posts. Fruit trees (Prunus spp.) are also common, while vines (Vitis vinifera) were an important crop but in recent years the vineyards have gone out of use. Pomegranate (Punica granatum) was only found in the cultivated state, though according to Bailey (1949, p. 721) it is a native from the Mediterranean to the Himalayas. Davis (1972, p. 174) has found that this plant is restricted to an elevation of between 250 and $600 \mathrm{~m}$.. while at Aşvan it was found in a sheltered position in the village at c. $715 \mathrm{~m}$. It is improbable that it would be found as charcoal: nevertheless there is always a chance that dead or moribund plants could be used as fuel if there was a shortage-as occurred at Aşvan in 1971. Black locust (Robinia pseudoacacia), a native of North America, is a commonly planted ornamental throughout Turkey. as is tree-of-heaven (Ailanthus altissima) which is a native of China. Oleaster (Elaeagnus angustifolia) is a common component of the hedgerows in irrigated areas where it is a competitive species due to its rapid growth and large, sharp spines. The wood is hard and thorny. it is used for fencing. fuel and ploughs. Whether this species is endemic in the region is a matter of doubt. Elms (Ulmus spp.) are also planted around the village, presumably both for timber and ornamental reasons. Hackberry (Celtis tournifortii), though undoubtedly indigenous in the region, is at present restricted to the hedgerow habitat. It is the most drought resistant species of this genus (Zohary, 1973, p. 366). The fruit is edible and occasionally exploited today. Similarly, hawthorn rCrataegus monogyna) is endemic and appears to survive in protected habitats. Bramble (Rubus spp.) are also common, but the Turkish Rubi are a poorly known genus (Davis. 
1972 , p. 30). A detailed study in the area might show them to be useful environmental indicators. In the Aşvan bölgesi some species exploit banks of streams and irrigation ditches, while others are found away from permanent water and may possibly be a different species. They were no doubt members of the original climatic climax flora which, since the coming of irrigation, were able to expand. The wood has no use, and its coarse prickles make it an undesirable shrub to collect for fuel. It may even have been protected for its fruit, making it an unlikely species to occur in charcoal deposits. Another spiny shrub, the matrimony vine (Lycium sp.) is found around the village. It is drought resistant by means of an adaptation whereby leaf fall occurs in the summer, so preventing excessive transpiration. Christ thorn (Paliurus spina-christi) is the most competitive of the spiny shrubs. Ecologically, it is not an important indicator because it has a wide tolerance, ranging over most of Turkey (Davis, 1967, p. 533). Its ferocious spines make it tolerant of overgrazed areas where it is an invasive weed, forming impenetrable thickets especially where the forest has been destroyed (Davis, 1967, p. 534). The shrub is occasionally cut to make corrals. Poplar (Populus spp.) is the most extensively cultivated tree, not only at Aşvan but throughout Eastern Anatolia where it is grown on irrigated plantations, the timber being used for a variety of purposes but most extensively in house construction. Also cultivated on a large scale is willow (Salix cf. alba) which is regularly pollarded.

2. The Valley Bottom Including the Flood Plain and Moist Habitats. The flood plain is occupied by a number of halophytic and steppic shrubs. Tamarisk (Tamarix smyrnensis) is the present dominant, being a common component of the Irano-Turanian vegetation along rivers in Anatolia and Iran (Zohary, 1973, p. 385). Prior to 1968 the flood plain had been virtually devoid of arboreal flora, but during the winter of 1968 a flood deposited a considerable layer of silt as the Murat burst its banks. Since then large areas have been invaded by tamarisk which spreads rapidly by suckers. This expansion made it possible for the village to exploit this area for tinder and fuel, whereas before it had relied more on dung because of a dearth of suitable shrubs. It is worth noting that within three years, despite the fact that half the population of the village had emigrated, much of the area had been cleared. On parts of the flood plain Xanthium echinatum is dominant, being resistant to domestic animals presumably as a result of its toxic qualities. Two leguminous perennials, liquorice (Glycyrrhiza glabra) and Alhagi pseudoalhagi, also compete, the latter having large spines, presumably an adaptation to resist grazing. The former spreads by a creeping rhizome, and is cultivated in many parts of Turkey; while Alhagi pseudoalhagi is more steppic and halophytic in its requirements (Zohary, 1973, p. 419) thus being fitted to a rather specialized niche. Of the arboreal species occupying unstable banks of the river, willows are the most common. Salix alba and $S$. auriculata were identified, but never were they seen to reach a height of more than $2 \mathrm{~m}$. before being destroyed by floods or cut by itinerant basket makers. Also occupying this habitat, though infrequently, is the chaste-tree (Vitex agnus-castus) which is a common riverine species in Eastern Anatolia. Noaea mucronata is a steppic spiny shrub; at Aşvan it appears to be restricted to the more sandy areas near the river and its wood is only 
suitable for fuel. Elder (Sambucus nigra), presumably a migrant from the Euxine region to the north, was found growing at spring heads. It is unlikely that this plant could survive away from a perennial source of water, having been spread to these habitats by migratory birds. Fig (Ficus carica) is found in moist habitats. The plant is favoured by local inhabitants for its fruit while its leaves are not browsed by animals, which makes this a competitive species.

3. The Upland Habitat. Most of this area is very heavily grazed, which has resulted in the expansion of grasses and herbs resistant to grazing, for example Euphorbia and Astragalus. Segetal einkorn (Triticum boeoticum) is found along field margins. Trees and shrubs are virtually absent save for the occasional hawthorn (Crataegus spp.), Paliurus spina-christi and sloe (Prunus spinosa) which were extremely dwarfed and gnarled, together with a small area of scrub oak supported by a north-facing slope in the extreme south-east of the region (see Fig. 1), where the hills rise to $1,240 \mathrm{~m}$. This limited area of relict forest would appear to owe its survival to its inaccessibility and the fact that it is north facing. Grazing is probably light because of the elevation, distance from water, and the steep incline with rocky outcrops which would deter shepherds. Stumps, with axe marks, prove that in the not too distant past it was exploited for timber. None of the oaks reached a height of more than $2 \frac{1}{2} \mathrm{~m}$., some may have been of considerable age judging from the closeness of the annual growth rings, and although timber of sorts could have been cut, no oak was found in use in the village today, even in the oldest buildings. A specific identification of the oak was not possible. However, Quercus brantii (with variants), $Q$. libani, $Q$. boissieri and probably $Q$. oophora have been reported on northern slopes between Malatya and Elâzı̆g (Zohary, 1973, p. 277). Shrubs in this area include hawthorn (Crataegus spp.), rose (Rose spp.) and wild almond (Amygdalus orientalis), the latter being typical of the Irano-Turanian region in this part of Turkey.

Because very little timber and no fuel is imported into the village at present, it seems fair to use the modern cultural situation as a point of departure into the past where it is hoped the evidence will allow us to evaluate the cultural, ecological and climatic factors affecting deforestation. The situation in the region at present is one of virtual destruction of the forest so that timber has to be obtained by cultivation. Some fuel is obtained from the flood plain though this appears to have become available only in recent years and in the recent past the villagers utilized cultivated trees or dungs.

\section{A NINETEENTH CENTURY REFERENCE (Cuinet, 1892, pp. 332-5)}

From the contemporary situation an initial step into the past can be made by this detailed and explicit report. Historical references, particularly by earlier writers, are so often too vague and generalized or in some cases misleading that they are of little use in cases such as this where a small area is involved, and although useful work can be achieved (for example, Rowton, 1967, pp. 261-77) it is very easy to be sceptical. For example, an area described as forested may since that time have been deforested and then afforested again, or as so often happens assumptions are based on negative evidence. Thus Rowton (1967, p. 274) states that there are no references to timber from the region of the vast catchment 
area of the Euphrates north of Malatya and therefore this area may never have been forested, yet even today wood is exported from Tunceli, and Cuinet (1892, pp. 332-5) reports timber being exported from near Erzincan.

Cuinet's report is a useful guide to the situation at the end of the last century when lead mines at Keban, $14 \mathrm{~km}$. downstream of Aşvan, were closed down for lack of wood on which they relied for fuel. The population of Keban fell from 3,000 to 300 households when fuel became scarce, for as Cuinet points out the forests had been destroyed without regard to conservation. The only local timber, the report goes on, was cultivated Populus and the villagers in the region were forced to burn dried dung for fuel. Harput, the historical town of Elâzı̆g, was affected and cedar (?) wood was imported from near Erzincan, but all timber was an expensive commodity. Of other arboreal species Morus spp., Elaeagnus sp., Ziziphus sp. and fruit trees were present, but Quercus spp. had virtually disappeared, and the only region of natural timber was that of Tunceli where Quercus sp. and Juglans sp. were exported in the form of large planks (4 m. X $20 \mathrm{~cm} . \times 20 \mathrm{~cm}$.).

Thus, from this report it would appear that the contemporary situation was reached by the end of the nineteenth century, and that a shortage of fuel and timber must have affected the economy of the region.

\section{METHODS}

Recovery. Charcoal occurs in deposits in many different forms, depending on its origin, from large carbonized beams to minute isolated fragments which require different methods of sampling. Large fragments at the four sites were gathered by hand; hearths were normally sampled in this way, while more diffuse structures were sampled by means of the water-sieve (see Williams, 1973, p. 288). These samples varied depending on their context, but in almost all cases the largest fragments were no more than $3 \mathrm{~cm}$. along their longest axis and many were much smaller. Samples of this kind represent all the charcoal from given archaeological features, e.g. pit floors, etc., from which a large volume of soil was watersieved, producing prodigious quantities of charcoal fragments, often forming a bulk of $20 \mathrm{~cm} \cdot{ }^{3}$ and comprising as many as six recognizable species. Clearly subsampling was necessary. Samples were laid out on paper and one quarter was removed and worked through systematically. Normally, species composition became constant with less than a quarter, though in certain cases it was felt necessary to work through a further quarter. By far the majority of charcoal from the water-sieve would have been missed without this technique; further, it is also an unbiased method of recovery in terms of size, shape and distribution. That samples from the water-sieve proved more rewarding in terms of species composition is shown below, expressed as a percentage of the total number of trench and water-sieved samples.

$\begin{array}{llll} & \begin{array}{l}\text { \% of separate } \\ \text { species }\end{array} & \begin{array}{l}\text { \% of samples with } \\ \text { more than 3 species }\end{array} & \text { \% of Indeterminates } \\ \begin{array}{l}\text { Water-sieved samples } \\ \text { (total 116) }\end{array} & 17 \% & 36 \% & 7 \% \\ \begin{array}{l}\text { Trench samples } \\ \text { (total 176) }\end{array} & 11 \% & 12 \% & 5 \%\end{array}$


The results emphasize the limitations of purely trench sampling. However, it has been shown that efficient recovery at any site is affected by a wide range of variable factors. Our evidence bears this out, and a more detailed examination of the data shows that the results are not constant from trench to trench or site to site. One atypical group of trench samples from G4A at Aşvan had a particularly large number of species. In the case of the Chalcolithic and Early Bronze Age levels only five trench samples were obtained, while over seventy were recovered using the water-sieve because charcoal from these periods becomes fragmented and dispersed by the mass of over-burden resulting in a large quantity of minute particles which would be missed by even the most careful excavator.

Sorting. The charcoal was sorted into recognizable groups with the aid of a hand lens before final identification under the microscope. These groups consisted of Quercus, other ring porous woods, Salicaceae, Gymnosperms, and other diffuse porous woods.

Bias in terms of size, shape or texture was an obvious hazard. This was overcome by working through all the material from each sub-sample. As an experiment, fragments of less than half a centimetre in length were selected and identified; the results showed that Quercus was less well represented, but there was no significant difference in species composition.

Examination of the material. Microscopic examination and identification were carried out using the normal methods (for further details see Dimbleby, 1967, pp. 104-16). An excellent key (Greguss, 1955 and 1959) with a set of photomicrographs of carbonized sections, from which the features for the key had been obtained, was used as a basis for identification, but had always to be backed up by the use of reference material in the form of identified modern carbonized samples collected the previous season. Lack of reference material was found to be the limiting factor: many specimens were only identified to the generic level, for example Quercus, Juniperus, Acer and Alnus, which could have been represented by a number of species not in the reference collection. During the last season the collection was greatly increased. Others presented less of a problem because the genera have only one species represented in Eastern Anatolia, for example Paliurus spina-christi, and Elaeagnus angustifolia, while some families on the other hand are difficult (though not impossible) to distinguish at the generic level, for example Salicaceae and Ulmaceae.

Recording and Quantifying. Results were recorded on two sets of cards, one being filed by genus, the other by archaeological position, for ease of cross reference and ordering into meaningful chronological groups or contexts. In addition, a general quantitative record was made, the quantity of charcoal being recorded in the following way: "abundant" $>25$ fragments, "medium" 5-25 fragments, "rare" $<5$ fragments for each sample. If a species represented $>90 \%$ of all the fragments in a sample, this was recorded, while in the case of large pieces they may have been recorded as beam or coffin, etc., and if over $10 \mathrm{~cm}$. along their longest axis they were given an abundant rating. 
A qualitative record of age was also carried out by counting the growth rings, but because of the fragmentary nature of the material it was necessary often to estimate the age by the curvature of the rings. In this case also three ratings were used: $<3$ years, 3-7 years, and $>7$ years growth. Both methods of analysis were found to be arbitrary and were only carried out at the time for the sake of completeness. The author believes that charcoal does not lend itself to a quantitative analysis given the variable factors which lead to its inclusion and preservation in archaeological deposits, for example preference, availability of timber, cultural taboo, functional variation; then there is the nature of the fire-whether natural or artificial-and also the property of the wood. Many workers in this field have pointed out the limitations of charcoal evidence because charcoals are artifacts which have been subjected to a cultural filter (Western, 1971, p. 33). Both Lona (1949, pp. 185-98) and Godwin together with Tansley (Godwin and Tansley, 1941, pp. 117-26) recognized that nothing more than generalized inference was legitimate. The results from Aşvan showed that the only reliable criterion for interpretation is presence of a species. This can be taken one step further if one compares the proportion of archaeological features, that is to say samples, containing a certain species from one period to another, and here cultural factors must always be taken into account. Negative evidence is problematical: it was felt, for example, that the absence of spiny shrubs in the early periods was significant, but it did not prove them to be absent in the region.

\section{THE SITES}

Aşvan Kale, the largest of the four hüyüks, lies at the edge of the present flood plain where several springs gush from beneath the conglomerate (see Fig. 1). The village plain to the south is one of the largest irrigable areas on the lower Murat. At this site charcoals were sampled by water-sieving and trench sampling from levels of nineteenth century, Medieval, Roman fourth century, Hellenistic and Early Bronze Age date. About $1 \mathrm{~km}$. to the east of Aşvan Kale, on the west bank of the Kuru stream, is the location of Çayboyu which has been eroded into by the stream. A $2 \times 2 \mathrm{~m}$. trench was excavated to virgin soil $6 \mathrm{~m}$. below the surface. All excavated earth from the trench was processed by the water sieve and found to produce prodigious quantities of charcoal. The site has been tentatively assigned to the Chalcolithic of the fourth millennium. Going south up the Kuru stream one passes across the village plain and fringing hills onto the upland basin, Taşkun Kale being located at its lower end on the west scarp of the valley of the stream on a natural hill affording a good view down the valley towards the Murat. This site was excavated primarily to investigate the Medieval deposits. There are, however, Early Bronze Age strata below. To the north, again on a small natural mound adjacent to a spring, at an elevation of $850 \mathrm{~m}$., lies Taşkun Mevkii. Chronologically this site has been assigned to the beginning of the third or end of the fourth millennium B.C. (for detailed accounts of the sites, see Aksoy and Diamant, Helms, McNicoll and Mitchell, 1973).

\section{RESULTS}

The four excavated sites can be divided into six broad archaeological phases: Nineteenth Century, from which 14 samples were obtained; Late Medieval, with 


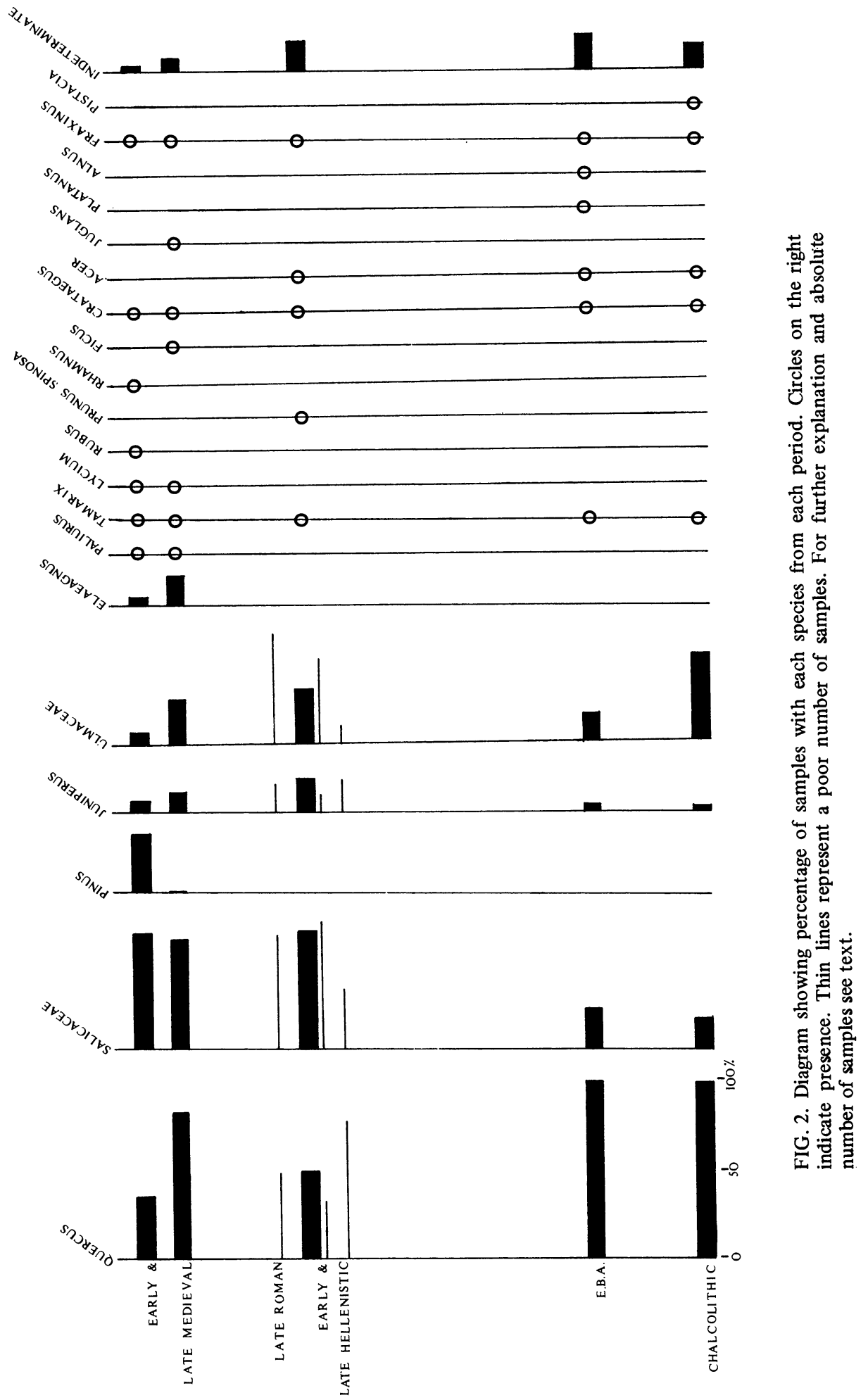


72 samples; Early Medieval (54), Roman and Hellenistic (41), Early Bronze Age (52), Chalcolithic (26). In addition 33 samples were found to be unstratified, making a total of 292 samples. A dearth of samples from the Roman and Hellenistic levels meant that these levels had to be combined, though uncombined results are given in Fig. 2. The relatively small number of samples from the Chalcolithic levels (26) were felt to be reliable because complete recovery by water-sieving over a depth of several metres favoured unbiased sampling.

To discover if more detailed stratified sequences existed, results from the step trenches cut into the Aşvan Hüyük from which samples were collected over several metres were plotted for each level (see Fig. 3) and the same procedure was carried out for Çayboyu (see Fig. 4). These results suggest that the less common

Acer Alnus Ulmaceae Crataegus Juniperus Fraxinus Platanus Quercus Saliaceae Tamarix Indeterminate

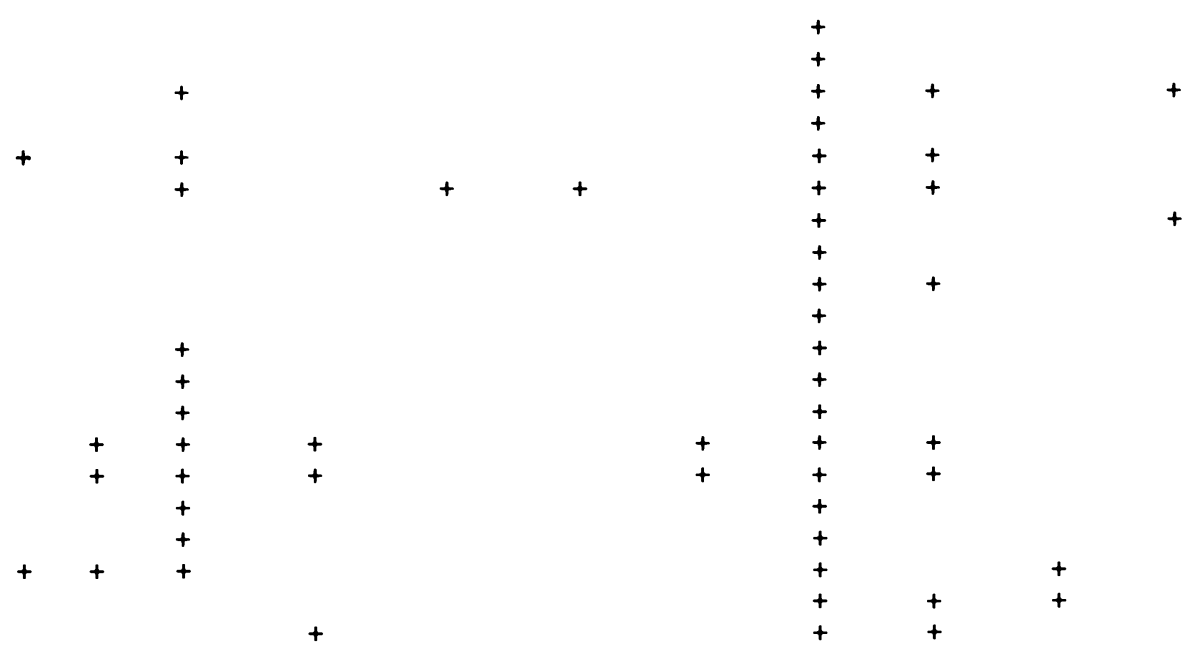

FIG. 3. Results of analysis from trench G2B at Aşvan showing presence of species in stratigraphical order.

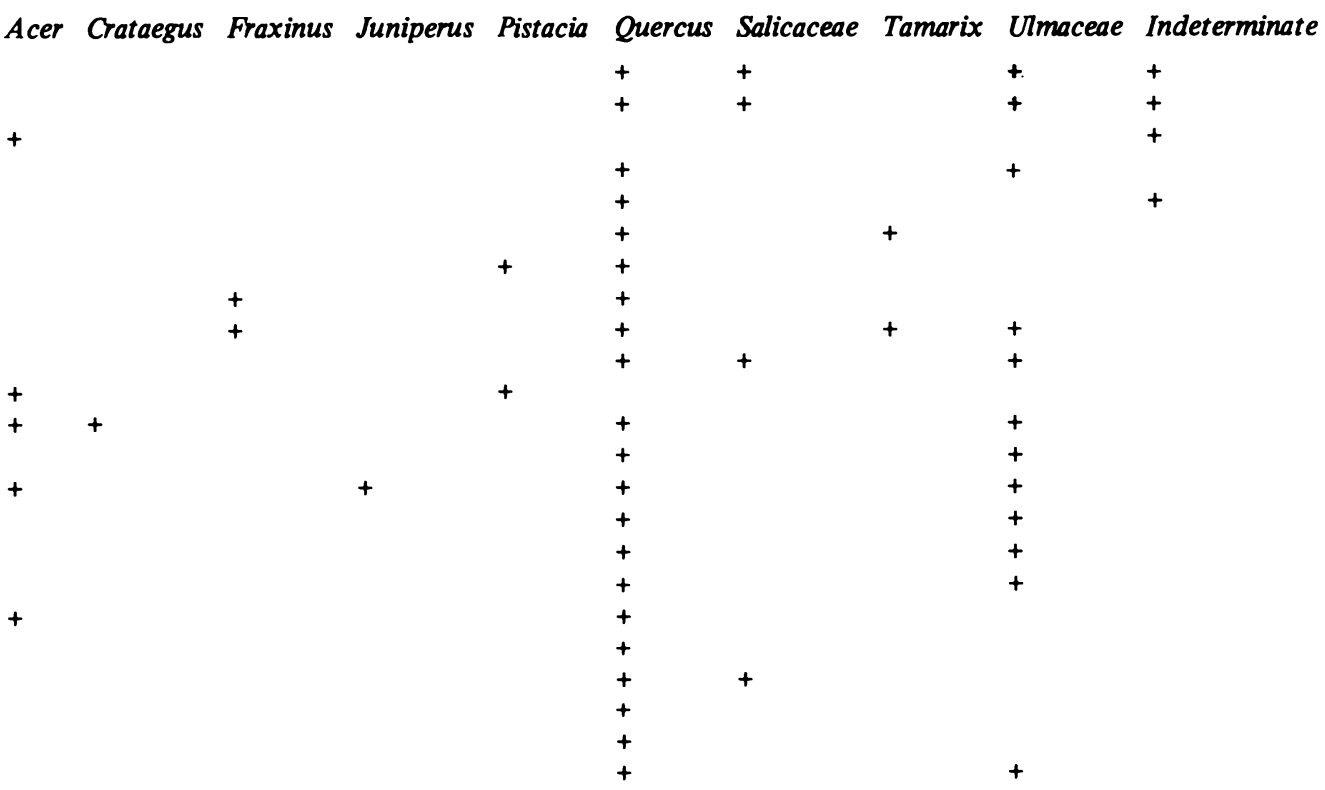

FIG. 4. Results of analysis from Çayboyu showing presence of species in stratigraphical order. 
species are arbitrarily distributed, which results from cultural and sampling bias, indicating that no sound conclusions can be made unless samples are very much larger. On the other hand, if we treat the samples as a contemporary whole and represent the absolute frequency of the presence of species in the form of a histogram (see Fig. 5), then we have a clear picture of the proportions of different

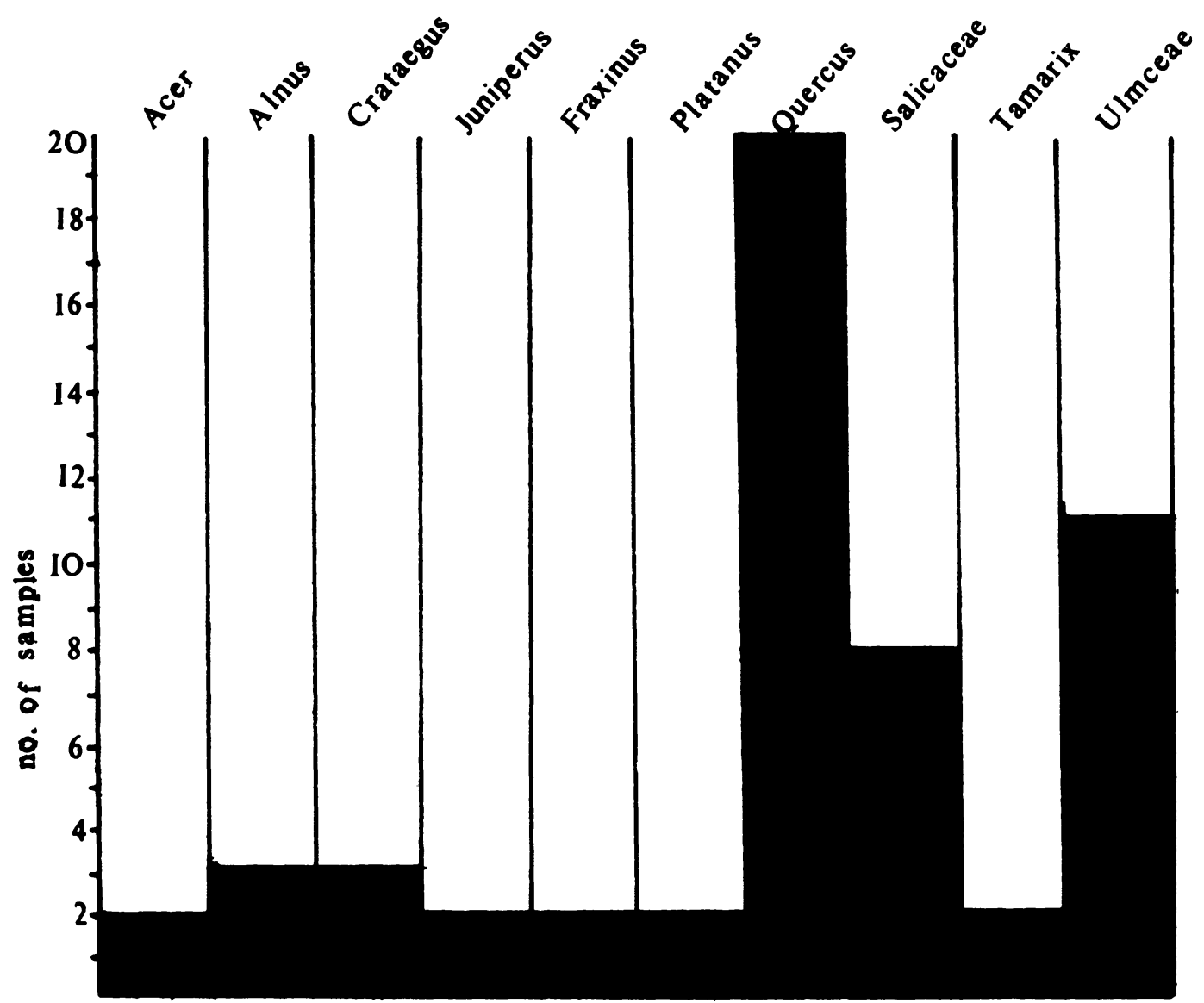

FIG. 5. Histogram: showing the relative occurrence of species in the 20 samples from the E.B.A. levels of trench G2b at Aşvan Kale.

species represented. It cannot be assumed that this reflects the species composition or frequency of the ancient forest; needless to say some inference can be made when one bears in mind the cultural influences affecting selection of firewood and timber. This emphasizes the need for large samples, and unless they are available only a very tentative interpretation can be made. For this reason it was thought advantageous to combine results from the four sites which all lie within a $5 \mathrm{~km}$. radius, despite the fact that the immediate environments of the sites vary (see Fig. 1). This variation in habitat between sites can be seen from the results, particularly with reference to hydrophilic species (see below)

$\begin{array}{lllll} & \text { Aşvan } & \text { Çayboyu } & \text { Taşkun Kale } & \text { Taşkum Mevkii } \\ \text { Platanus } & + & & & \\ \text { Alnus } & + & & & \\ \text { Tamarix } & + & + & & + \\ \text { Salicaceae } & + & + & + & +\end{array}$


suggesting that wood was collected from no great distance, at least in the early periods. But, as Godwin and Tansley (1941, p. 117) point out, assumptions of this kind are apt to be dangerous.

Fig. 2 shows the results of identifications from samples as a percentage of all the samples in each period. Thus interpretation is based on presence and absence in any one archaeological feature, i.e. layer, pit, grave, etc., and not on quantity or weight of charcoal which, because of the random factors which lead to its inclusion in a deposit, could be very misleading. For example, a rare species might by chance survive as a large fragmented carbonized beam which would distort the overall picture, but using the presence and absence method at least some of the variable factors are ironed out.

Specific identifications were found to be difficult owing to the huge range of possible species and lack of reference material, despite the fact that a comprehensive collection had been made of the area the previous year, and one could not rule out the possibility of species extinct in the region today occurring in deposits. The Salicaceae were not identified to generic level because this would have been time-consuming given the amount of charcoal from this family. This group then represents both cultivated and wild forms of Populus and Salix. Pine (Pinus), an unexpected genus to be found, was not identified beyond generic level owing to lack of reference material. For the Ulmaceae it is likely, both on anatomical and ecological grounds, that this family is represented by Celtis spp., but it must be mentioned that many of the samples, particularly charcoal from young branches, would have been difficult to distinguish from Ulmus. Ficus, Elaeagnus, Paliurus, Tamarix and plane (Platanus) resemble their modern counterparts from the region, while Rubus, Crataegus, maple (Acer), ash (Fraxinus) and pistachio (Pistacia) could have represented any one of a number of species.

\section{INTERPRETATION OF THE RESULTS}

The results shown in Fig. 2 reflect the availability, preference and possibly also aspects of utilization of woods collected by the inhabitants at different periods in time, and not the forest composition. But as has been pointed out, inference can be made about the changing state of the vegetation, particularly from those species which are well represented, e.g. Quercus, Salicaceae, juniper (Juniperus) and Ulmaceae. Others are more specific indicators. Furthermore, we have the modern situation in terms of vegetation, utilization and the inclusion of charcoal in deposits in the modern villages using traditional methods as a framework on which to hang the evidence.

Quercus, the theoretical dominant and therefore a good indicator as to the state of the forest, is not used in Aşvan today, the small relict region is too small and does not provide usable timber for the needs of the villages in the region. During the late Medieval period it is found representing a relatively small proportion of the charcoal, and much was immature wood possibly indicating a degenerate scrub forest, increasing however in the early Medieval phase, but again being poorly represented in the Roman and Hellenistic levels, only to expand as a major species in the Early Bronze Age and Chalcolithic periods. That this represents availability cannot be proven. However, it does broadly agree with the Quercus frequencies obtained by pollen analysis (van Zeist, 1968, pp. 19-39) of 
sediments from a lake near Gölbaşı, $120 \mathrm{~km}$. south-east. Van Zeist suggests that increased human activity in the first millennium B.C. resulted in forest degradation; the date being arrived at by extrapolation of rates of deposition combined with one radiocarbon date. Our more accurate dates, but less reliable samples, suggest for the Aşvan region that Quercus was less available in the first century B.C. than the second, but becoming more available by the fourth century A.D. The Salicaceae (poplar and/or willow) are roughly complementary (see Fig. 2). In the Chalcolithic and Early Bronze Age they represent a small proportion of the total, less than Celtis. Yet by the Hellenistic and Roman levels they form a higher proportion than Quercus and would surely have become extinct unless cultivated. Possibly because of a shortage of fuel and timber, either Salix or Populus appear to have been planted. The ecological requirements of Populus (the most likely species) would imply that by this stage at least irrigation was practised. This interpretation must be treated with caution because the results may represent preference for certain timber. In the modern villages Populus is the only cultivated timber tree, save for the occasional Morus and Ulmus which are felled, and Salix which is pollarded.

While Salicaceae are abundant in the late Medieval phase, it is partly replaced as a timber wood by Pinus which is present in a high proportion of samples as charred beams from a destruction phase at Aşvan Kale. Relatively fewer samples came from the same phase at Taşkun Kale, and one specimen came from the early Medieval phase. Today Pinus is absent from the region. The nearest reports are of $P$. brutia and $P$. sylvestris $120 \mathrm{~km}$. north on the other side of the Munzur mountains near Erzincan (See Davis, 1965, pp. 72-4). P. brutia and P. nigra occur $120 \mathrm{~km}$. south-west between Malatya and Gölbaş1. Compared with Populus it seems unlikely that it would have been cultivated in ancient times, or transported any great distance as timber. It is also unlikely that it would have been growing upstream of Aşvan. It should be noted here that a pollen diagram from Urfa (van Zeist, 1968, pp. 19-39) shows a peak of Pinus pollen in its upper levels, but Ufra would seem too distant for comparison. If Pinus was indigenous in the region, which species would it be likely to have been? $P$. brutia is indicative of Mediterranean climate (Zohary, 1973, p. 343), while $P$. sylvestris and $P$. nigra are more tolerant of continental conditions. Of the latter two, $P$. nigra is not separated by a barrier, in this case the Munzur, and is therefore the most likely. Cuinet noted that timber was imported to Harput, the provincial capital, from near Erzincan at the end of the last century, and there is no reason to suppose that similar transportation did not occur in the fourteenth century. It seems the most plausible explanation and would indicate a severe shortage of timber.

Juniperus is also a species not found in the Aşvan bölgesi, although excursions for reference material in the foothills of the Munzur, $40 \mathrm{~km}$. to the north, show that two species, $J$. excelsa and $J$. oxcycedrus exist either as isolated plants by sheltered rock outcrops or as an understory species in the Quercus associations. Juniperus shows a slight increase in the later periods, possibly because the dominant was becoming scarce, but then becomes extinct between the late Medieval and the present despite the fact that it is not browsed heavily by sheep or goat and it is effectively spread by birds. In other words it would appear to be a competitive species. An explanation for its extinction is suggested by Guest 
(1966, p. 107), who notes that $J$. oxycedrus in Iraq does not exist outside the forested areas, indicating that it may only survive as an understory shrub. Other reports (Zohary, 1973, p. 349) are contradictory, suggesting that deforestation favours an expansion of $J$. oxycedrus. Clearly there is not enough evidence to use this species as an indicator and so far it has only been possible to identify the charcoal to generic level.

The Ulmaceae are well represented, being second to Quercus and Salicaceae. As mentioned, samples closely resemble Celtis tournifortii, a species extant in the region. However, the possibility of Ulmus being present cannot be ruled out. On the other hand, it is unlikely that this genus would have formed a large proportion as it usually occupies moist habitats and is rare everywhere in Turkey with the exception of certain Euxine forests. Chalcolithic levels have a high proportion of this group which points to its importance in the climatic vegetation, though it could not be referred to as a dominant. This is significant because this genus is likely to be under-represented in pollen diagrams. The group also has relatively high frequencies for the later periods where again a shortage of Quercus may have led to more extensive exploitation. Celtis tournifortii today occupies the hedgerow habitat which offers protection against domestic animals.

Of the remaining shrubs, all but Tamarix occur during, or after, the first century B.C., with the exception of Pistacia which is only present in the Chalcolithic. Shrubs like Paliurus spina-christi will have expanded as a result of forest degeneration in the later periods, this shrub being particularly resistant to animals. The same is probably true, though on a lesser scale, for Lycium, Prunus spinosa, Rubus, Ficus and Rhamnus. The evidence suggests that these species expanded before, or during, the Medieval period. Elaeagnus-almost certainly $E$. angustifolia-may be an introduction. Today it only survives in irrigated areas and was not seen growing in its natural habitat in Eastern Anatolia. Its centre of origin has not been located (Zohary, 1973, p. 631), and since it has been in cultivation for some time over a wide area, it seems probable that it was introduced to Aşvan some time prior to, or during, the early Medieval period. This interpretation would account for its sudden appearance.

The least well represented trees occur more frequently in the Chalcolithic and Early Bronze Age periods, save for Crataegus which is probably the least susceptible to the anthropogenic factors. Acer, Platanus, Alnus and Fraxinus may have succumbed to the effects of man because this area is a marginal habitat for them. All are present in the steep, more isolated and sheltered valleys of the Munzur where the impact of man has been less severe, which, combined with a more favourable microclimate, has favoured their survival. These regions also support Pistacia eurycarpa and $P$. vera. The former would appear to be indigenous (Zohary, 1973, p. 277), the latter an introduced cultivar (Zohary, 1973, p. 630).

Of the introduced species only Morus sp. was identified; the specimens, all uncarbonized, came from the nineteenth century graves.

The specific identification of species, particularly Pistacia, would undoubtably lead to a more reliable interpretation of climatic, human and other ecological factors. To take this genus as an example, seven species of Pistacia occur in the Near East. Some are characteristic of the Mediterranean region, others the IranoTuranian region, while one is common to both. Taxonomically, they fall into 
three groups (Zohary, 1973, pp. 368-70) which, bar P. atlantica, coincide with the phytogeographical regions (see below).

$\begin{array}{llll}\text { Groups } & \text { Mediterranean Region } & & \text { Irano-Turanian region } \\ 1 & \text { P. terebinthus } & & \\ 2 & \text { P. palastina } & \text { P. altanlical } & \\ & & & \text { P. vera } \\ 3 & \text { P. lenticus } & & \text { P. eurycarpa }\end{array}$

If these species could be separated on anatomical grounds, and more material were available from the Near East, one might hope to clarify the past distribution of the Mediterranean flora.

With the present list of identified species it is not easy to disentangle what might be the human or climatic factors influencing the presence and absence of certain species from the samples. It is noticeable that certain shrubs characteristic of the Irano-Turanian region are absent, for example Amygdalus orientalis, Artemisia and Noaea mucronata. However, only two specimens of the first were located in the area, while the latter two are also restricted in terms of habitat. Furthermore, these species may be represented by the indeterminates. On the other hand, the list of species from the Early Bronze Age and Chalcolithic strata suggest more temperate conditions than those of the present day. This may, however, be more apparent than real, for many of the trees present in the early levels are riverine types which are restricted to small vulnerable habitats, frequently in close proximity to settlements. On theoretical grounds deforestation (which is unequivocally shown by the results) would lead to changes in the ecosystem, allowing steppic species either to invade or expand. Whether they were present before and have subsequently expanded or invaded from another region is impossible to determine from the evidence so far, and until more specific results are obtained one must accept the possibility, albeit unlikely, that species of Quercus, Celtis and Juniperus have undergone migrations in the region over the past 5,000 years.

\section{CONCLUSION}

The analysis of charcoal from the sites has revealed which genera, and in some cases species, were used for fuel and timber. Any interpretation of the results has to be tentative because it is not possible to show whether differences in species composition are due to preference or availability, but it is clear that the present state of the vegetation was not reached until after the late Medieval phase and quite possibly not until the nineteenth century. From the evidence it would appear that during the period of occupation none of the more temperate species of the Euxine forests to the north-for example Fagus, Corylus, Castanea, Abies and Carpinus-were present. Specific identifications would have furnished more detailed ecological evidence had they been possible at the time, and would certainly prove a useful area of study in the future. For this reason also it is not possible to make inferences about small climatic changes which may have taken place. With the evidence at present one can suggest that during the Chalcolithic and Early Bronze Age periods it would appear that the climatic climax vegetation was being exploited for fuel and timber-how continuously or extensively in 
terms of area is impossible to establish. However, in composition it would fit comfortably into the theoretical Kurdo-Zagrosian association. By the first century B.C. either a shortage of timber resulting from progressive exploitation for timber, overgrazing by domestic animals and possibly indiscriminate use of fire, or preference, led to the cultivation of timber, probably Populus, which would have required irrigation. Increased use of Juniperus and Celtis, presumably for fuel, is also evident. There was possibly slight regeneration by the early Medieval phase and by this time the spiny shrubs were coming into use as an alternative source of fuel, having expanded and colonized deforested areas around the settlements. During the late Medieval phase continued pressure resulted in Quercus largely being replaced by salicaceous and Pinus timber on the sites, and it is not inconceivable that the Quercus represented was gathered from more distant areas. This may also be true on a greater scale for Pinus. It is probable that areas of forest remained in less populated regions until the large scale organized exploitation by the Keban mines caused virtual obliteration in the region as a whole.

\section{ACKNOWLEDGEMENTS}

I am grateful to the following whose help made my work possible: Gordon Hillman for identification of the specimens for the reference collection and for providing many useful suggestions; Marian Phillips who helped record and sort the charcoal; Dr. D. H. French who provided the facilities and allowed me to examine the material; the British Institute of Archaeology at Ankara for financial support and Professor Dimbleby, my teacher.

\section{BIBLIOGRAPHY}

AKSOY, B., DIAMANT, S., 1973. “Çayboyu 1970-71”, Aşvan Interim Report, Anatolian Studies, XXIII, 97.

BAILEY, L. H., 1949. Manual of Cultivated Plants, New York.

CUINET, V., 1892. La Turquie d'Asie: Géographie administrative, statistique, descriptive et raisonnée de chaque province de L'Asie-mineure, Vol. II, Paris.

DAVIS, P. H., 1965, Flora of Turkey I; 1967, Flora of Turkey II; 1969, Flora of Turkey III; 1972, Flora of Turkey IV, Edinburgh.

DAVIS, P. H., et al., 1971. Plant Life of South-West Asia, Edinburgh.

DIMBLEBY, G. W., 1967. Plants and Archaeology, London.

FRENCH, D. H., 1973. “Assvan 1968-72: The Excavations”, Anatolian Studies, XXIII, 73.

GODWIN, H., TANSLEY, A. G., 1941. "Prehistoric Charcoals as Evidence of Former Vegetation, Soil and Climate", Journal of Ecology, XXIX, 117.

GREGUSS, P., 1955. Identification of Living Gymnosperms on the Basis of Xylotomy, Budapest.

GREGUSS, P., 1959. Holzanatomie der Europäischen Laubhölzer und Straücher, Budapest.

GUEST, E., (ed.), 1966. Flora of Iraq, Vols. I and II, Baghdad.

HELMS, S., "Taşkun Mevkii, 1970-71", Aşvan Interim Report, Anatolian Studies, XXIII, 109. LONA, F., 1949. Rivista di Scienze Preistoriche, IV, 187.

McNICOLL, A., 1973. "Taşkun Kale", Aşvan Interim Report, Anatolian Studies, XXIII, 159.

MITCHELL, S., 1973. "Assvan Kale”, Aşvan Interim Report, Anatolian Studies, XXIII, 121.

ROWTON, M. B., 1967. "The Woodlands of Ancient Western Asia", Journal of Near Eastern Studies, 26, 261.

WAGSTAFF, M., 1973. "Physical Geography and Settlements", Aşvan Interim Report, Anatolian Studies, XXIII, 197.

WESTERN, C. A., 1971. "The Ecological Interpretation of Ancient Charcoals from Jericho", Levant, III, 31.

WILLIAMS, D., 1973. "Flotation at Siraf", Antiquity, XLVII, 288.

VAN ZEIST, W., 1968. "Studies of Modern and Holocene Pollen Precipitation in South-East Turkey", Palaeohistoria, XIV, 19.

ZOHARY, M., 1973. Geobotanical Foundations of the Middle East, Vols. I and II, Amsterdam. 